\title{
過共晶 Al-Si 合金の初晶シリコンの微細化について
}

\section{久恒中陽: 西田 司 ${ }^{k: 1:}$}

Refinement of primary silicon in hyper-eutectic Al-Si alloy

(UDC 669. 715'782: 548 . 23)

HISATSUNE Chuyo**. NISHIDA Tsukasa***

Effects of phosphor and other elements added to the hyper-eutectic Al-Si alloys, containing $20 \%$ of silicon on the microstructure of alloys are studied.

The results of the experiments are summarized as follows:

(1) Excellent refining effect of primary silicon were obtained by the addition of As as well as $P$, when each content is not less than $0.03 \%$.

(2) With the addition of $\mathrm{P}$ and As, on the cooling curves appearing the remarkable difference in comparison with other element.

(3) Electromicroscopic examination of the refined silicon with the addition of $P$ and As revealed a ting crystal shapes.

The result of the experiments supported the hetrogeneous nucleation theory, commonly believed to be the mechanism of phosphorous refinements.

(Received Jan. 9, 1965)

\section{1. 序言}

過共晶 Al-Si 合金は, 熱膨張係数が小さく, 耐磨耗性 が優れていること，执よ゙鋳鉄に比し重量が軽いことな どの種々の利点を有するために, 自動車のエンジンのシ リンダーやライナーなどに適しており広く利用される傾 向にある。しかし，この合金はSi含有量が共晶成分以上 になると, 初晶Siが粗大に晶出し，機械的性質を悪くす るとともに，機械加工性に悪影響をおよぼす欠点を有し ている。それゆえ，この初晶Siを微細化することが問題 となり, 多数の研究が行なわれてきた。これらの研究の 結果, 初晶 $\mathrm{Si}$ の微細化処理として, 溶湯中に何らかの形で リンを添加すればもつとも効果があることが明らかにさ れた。その初晶 $\mathrm{Si}$ の微細化の機構として, Löhberg ${ }^{1)} お$ よびA.Cubula2)により提案された“異種核説”がもつとも 一般的に支持されている。しかし，この説は理論的には 実験事実をよく説明しうるが，実験的な確証の点ではま だ十分でないと思われる。

本実験では，この微細化機構を明らかにする目的でリ ンと同様にアルミニウムと化合物を生成すると考えられ る元素，およびリンと同属の元素など 7 種類の元素を撰
択しこれらを添加した場合，初晶Siにおよぼす影響，冷 却曲線，電子顕微鏡観察を主体に実験を行なつたので実 験の結果を報告する。

\section{2. 添加元素, 冷却速度, 添加量等の影響}

\section{1 実験方法}

供試料は市販のAl-Si合金で，その化学組成は Table 1 に示す。

一回の溶解量は, 約 $150 \mathrm{gr}$ とし, 黒鉛ルツボを用いて 電気炉で溶解した。溶湯温度 $850^{\circ} \mathrm{C}$ とし，その温度でそ

Table 1 Chemical composition of specimen.

\begin{tabular}{l|c|c|c|c}
\hline element & Si & Fe & Cu & $\mathrm{Al}$ \\
\hline weight $\%$ & 20.09 & 0.29 & 0.02 & other \\
\hline
\end{tabular}

Table 2 Kinds of mould and cooling rates.

\begin{tabular}{l|c|c}
\hline Kinds of Mould & Size (mm) & $\begin{array}{c}\text { Cooling Rate } \\
\left({ }^{\circ} \mathrm{C} / \mathrm{sec}\right)\end{array}$ \\
\hline Sand & $\phi 20 \times 50$ & 2 \\
Graphite(I) & $\phi 35 \times 25$ & 22 \\
Graphite(II) & $\phi 20 \times 25$ & 40 \\
Metal & $\phi 20 \times 50$ & 55 \\
Graphite(III) & $\phi 10 \times 25$ & 200 \\
\hline
\end{tabular}

\footnotetext{
* 軽金属研究会第24回大会にて発表

*:: 名古屋大学工学部教授 工博 Prof. Faculty of Eng., Nagoya University, Dr., Eng.

**** 名古屋大学工学部 Faculty of Eng., Nagoya University
} 


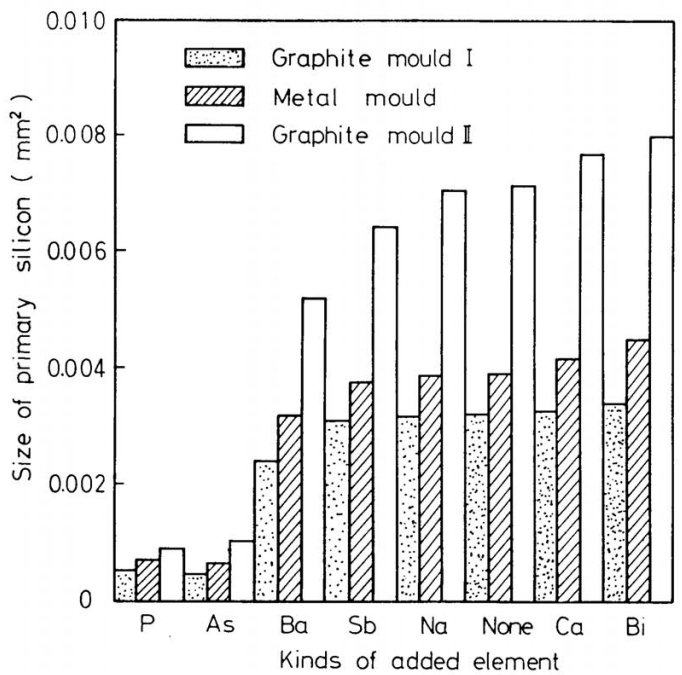

Fig. 1 The effect of added elements on the size of primary silicon $(0.05 \%$ added).

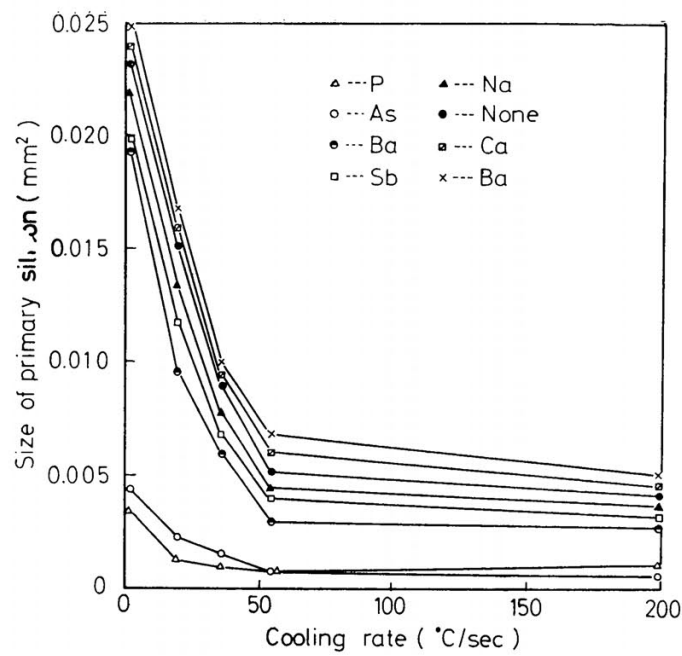

Fig. 2 The effect of cooling rates on the primary silicon.

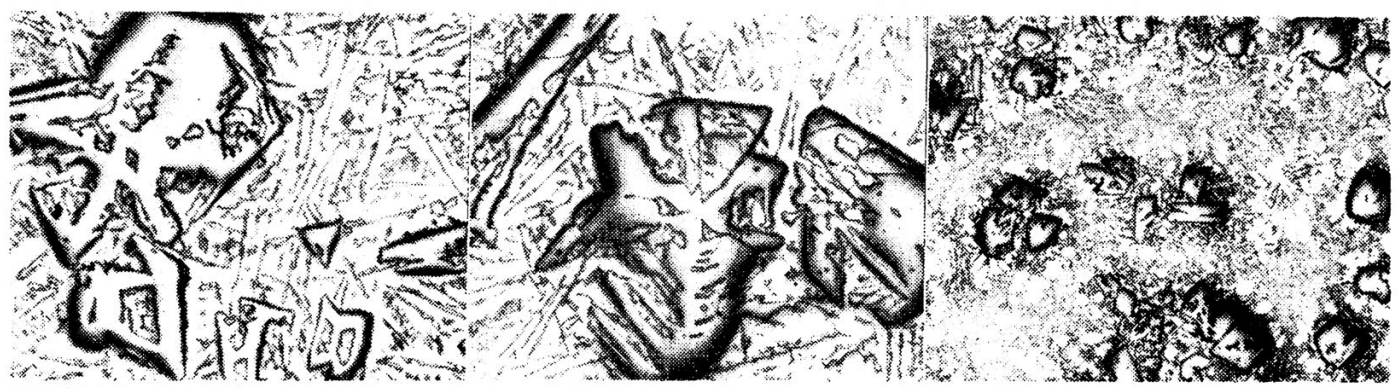

a) $\mathrm{Bi} 0.05 \%$, sand.

b) $\mathrm{Ca} 0.05 \%$, sand.

c) $\mathrm{Ba} 0.05 \%$, graphite (III).

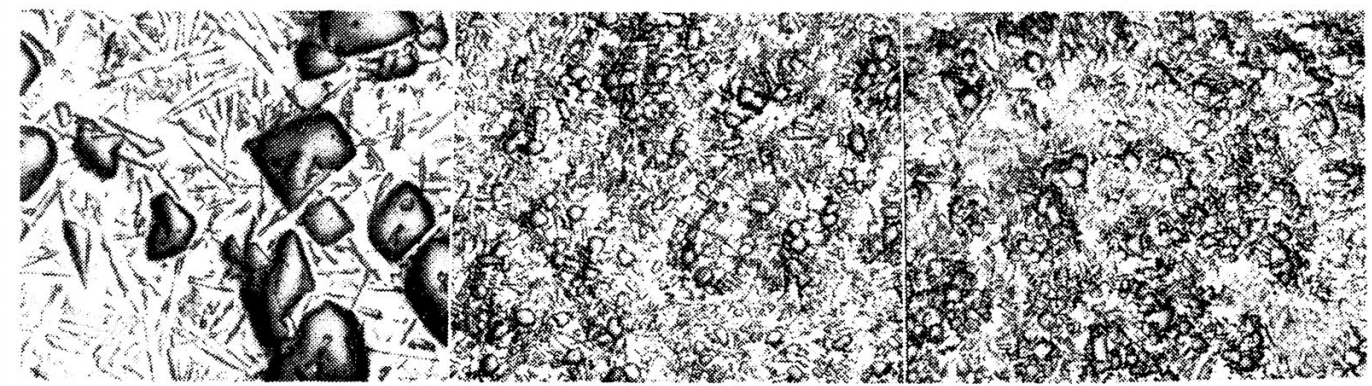

(d) $\mathrm{b}$ Sb $0.05 \%$, metal.

e) P $0.05 \%$, ntetal.

f ) As $0.05 \%$, graphite (I).

Photo. 1 Microstructures of specimens owing to added elements. (as cast, $\times 100$

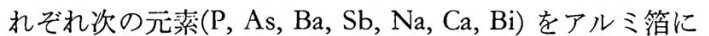
包んで添加した。添加後数分間保持した後 Table 2 に示 すごとき冷却速度を 5 段階に変えた鋳型え鋳込んだ。

冷却速度は電磁オシログラフを用いて測定したもの

で，測定位置は各鈸型の中央部え横から熱電対を捜入し て測定した。Table 2 に示す冷却速度は鋳込温度から共 晶温度までの冷却凝固区間の泠却速度を表わした。

添加量はそれぞれ0.005\%〜0.1\%である。

これらの試料の初晶 $\mathrm{Si}$ の大きさを研磨面の面積で比較 するため, 縱横に平行に基盤目盛が刻まれた読取り接眼
レンズを用いて，その目盛を占める数を読み取つた。 1 目盛の面積は $12 \times 7$ 倍の倍率で $0.0028 \mathrm{~mm}^{2}, 48 \times 7$ 倍の倍 率で $0.000175 \mathrm{~mm}^{2}$ である。以上のごとく初晶 $\mathrm{Si}$ 占める 目盛りの数を各試料について20ケ求めてその平均值を初 晶 $\mathrm{Si}$ の大きさとした。

\section{2 実験 結果}

添加元素による影響を添加量 $0.05 \%$ について調べた結 果はFig. 1 に示す通りである。Fig. 1 から解るとおり， Pを添加した場合およびAsを添加した場合は，他元素を 添加した場合に比べ, 非常に顕著な差違が認められ, 微 
細化程度は著しい。しかも，P と As は微細化程度にほ とんど差違が認められない。一方若干粗大化傾向を示す 元素はBi および Cuである。しかし粗大化傾向自体はそ れほど大きいものではない。ただし粗大化傾向を有する 元素を添加すると初晶 $\mathrm{Si}$ の形状が他に比べ特異なものと なる。

わずかに微細化される元素は $\mathrm{Ba}, \mathrm{Sb}, \mathrm{Na}$ である。

Photo. 1 は添加量0.05\%した場合，これら試料の研磨面 の顕微鏡写蒖を示したものである。

Photo. 1 a b から解るとおり，Bi，Ca など粗大化傾 向を有するものは, 冷却速度が遅くなると, 星型, 鉷型 をなし不規則で粗大な初晶Siを示している。一方微細化 効果の大なるPおよびAsを添加した場合は Photo. 1 c,d に見るごとく，その形状は規則的で粒状である。添加元

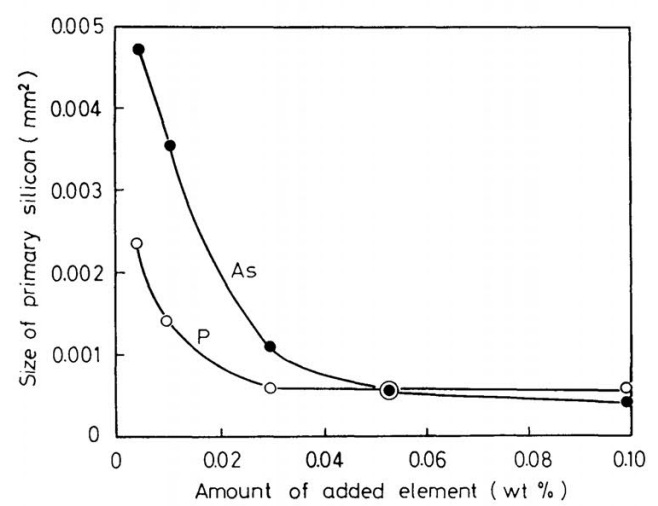

Fig. 3 Relations of the amount of added element and primary silicon.
素により初晶 $\mathrm{Si}$ の大きさに差異が生ずるとともにそれら の形状においても著しい美異が認められた。

Fig. 2 は各種源加元素を加えた場合, 初晶 $\mathrm{Si}$ の大きさ におよぼす彾却速度の影響を示したものである。

PおよびAs以外の元素を添加した場合は，冷却速度の 影響を著しく受け，金型すなわち汾却速度 $55^{\circ} / \mathrm{sec}$ まで はほぼ直線的に初晶Siの大きさは細かくなる。しかしP, As 添加した場合は冷却速度の影響をあまり受けず十 分微細化された初晶Siがえられる。この現镙は冷却速度 が大になると過冷を起し微細な結晶がえられる。いわゆ る急冷による微細化現象では説明されないのである。P およびAsを添加した場合の微縕化見象は過泠現象以外 にその因があるものと考えられる。すなわちこの二種の 元素は溶湯中または凝固に際し, 初晶 $\mathrm{Si}$ 微細にする特 異の作用をもつものと考える方が適当である。添加量と 初晶 $\mathrm{Si}$ の大きさの関係についてみると, 微細化効果のな い元素の場合は，形状に若干の差異が認められるのみ で, 大きさには変化はない。一方 PおよびAsを添加した 場合はFig. 3 に示すとおり添加量により変化が認められ る。添加量 $0.03 \%$ 以上場合には, それ以上添加しても 効果はほとんどなくほぼ一定である。0.03\%以下では效 果は減少するが $0.005 \%$ 添加でもなおわずかにその効果 が現われている。

添加量 $0.05 \%$ を境にして添加量が多くなるとAs の方 が初晶 $\mathrm{Si}$ は若干小さくなり，それ以下では逆に $\mathrm{P} の$ 方が 微細化されるような結果が現われた。しかしFig.3では 添加量を重量パーセントで示したものであるが，これを

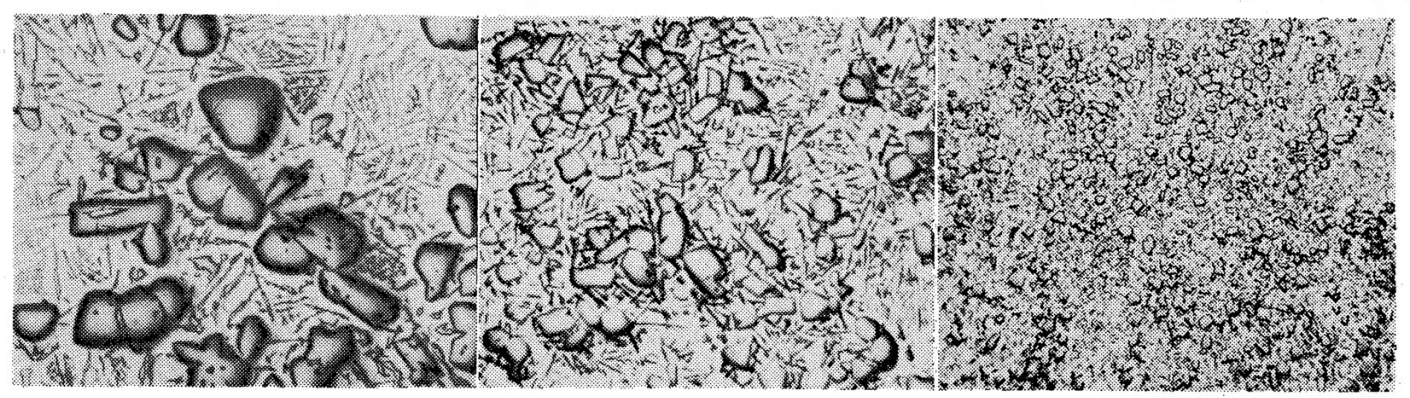

a) As $0.005 \%, 800^{\circ} \mathrm{C}$ cast,

b) $\mathrm{P} 0.01 \%, 800^{\circ} \mathrm{C}$ cast,

c) As $0.05 \%, 800^{\circ} \mathrm{C}$ cast,

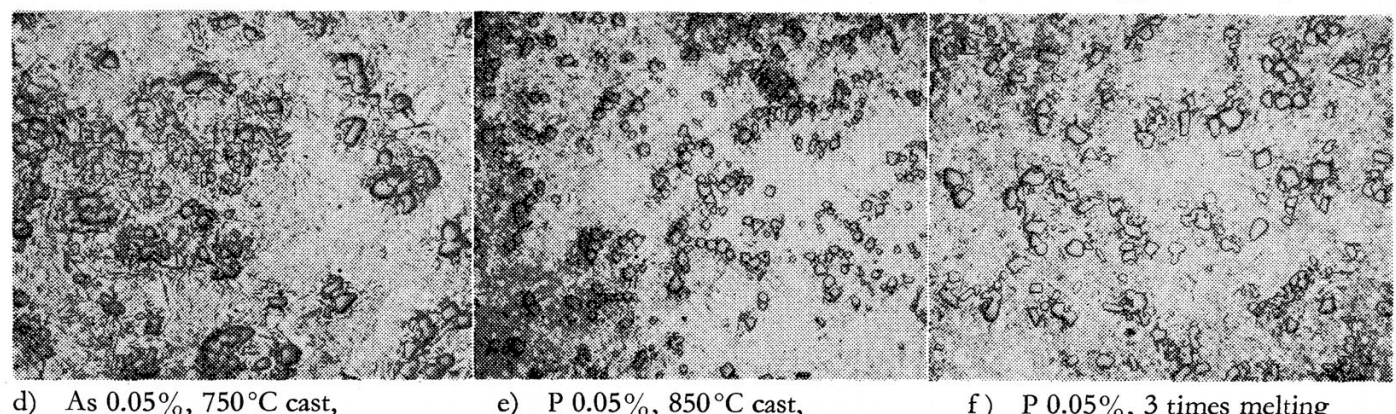
d) As $0.05 \%, 750^{\circ} \mathrm{C}$ cast,
e) $\mathrm{P} 0.05 \%, 850^{\circ} \mathrm{C}$ cast,
f) $\mathrm{P} 0.05 \%, 3$ times melting

Photo. 2 Microstructures of specimen owing to several condition (metal mould, as cast $\times 100$ ). 
Table 3. Added clements and crystal structures of their compounds.

\begin{tabular}{|c|c|c|c|}
\hline $\begin{array}{l}\text { Added } \\
\text { element }\end{array}$ & Compound & Crystal structure & $\begin{array}{l}\text { Lattice } \\
\text { constant }\end{array}$ \\
\hline $\begin{array}{l}\mathrm{P} \\
\mathrm{As}\end{array}$ & $\begin{array}{l}\text { AlP } \\
\text { AlAs }\end{array}$ & $\begin{array}{l}\text { Diamond }(Z n S \text { type }) \\
\text { Diamond }(Z n S \text { type })\end{array}$ & $\begin{array}{l}a=5.43 \\
a=5.63\end{array}$ \\
\hline $\mathrm{Ba}$ & $\mathrm{BaAl}_{4}$ & B.C. tetragonal & $\begin{array}{l}a=4.54, \\
c / a=246\end{array}$ \\
\hline $\mathrm{Sb}$ & AlSb & Diamond type & $a=6.13$ \\
\hline $\mathrm{Ca}$ & $\mathrm{CaAl}_{4}$ & B.C. tetragonal & $\left\{\begin{array}{l}a=4.36, \\
a=256\end{array}\right.$ \\
\hline $\begin{array}{l}\mathrm{Na} \\
\mathrm{Bi} \\
\mathrm{Si}\end{array}$ & & $\begin{array}{l}\text { B.C. cubic } \\
\text { Hexagonal } \\
\text { Diamond type }\end{array}$ & $\begin{array}{l}a=4.29 \\
a=4.75 \\
a=5.42\end{array}$ \\
\hline
\end{tabular}

原子パーセントに換算してみると，両者の差違はほとん どなくなり，おおむね同様な曲線をたどるのである。この ことは両者が微紐化に非常に効果がある理由を探求する 上で，大いに興味ある結果を示していると思われる。す なわちP扰よびAsを溶湯に添加すると，これらが化学当 量的な量的関係で作用していると考えられる。これに対 する詳細な考察は後述する。またこれらの鋳込温度拄よ び再溶解の影響を調べた結果, 䤣込温度は $800^{\circ} \mathrm{C}$ 以上で はあまり変化はみられなかつたが， $750^{\circ} \mathrm{C}$ 以下では若干 効果が減少する傾向がみられた。

Photo.2 の a,b およびcは $\mathrm{P}$, As を添加した場合，鋳 込温度 $800^{\circ} \mathrm{C}$ とし添加量を変えた場合の顕微鏡組織を示 したものである。Photo. 2 の b,e は鋳込温度 $750^{\circ} \mathrm{C}$ およ び $850^{\circ} \mathrm{C}$ とした場合の等真である。Photo. $2 \mathrm{f}$ は 3 回溶 解凝固を繰り返したもので，若干初晶 $\mathrm{Si}$ は大きくなつて いるが，微細化効果は十分保持され，溶解の繰り返しに よつて微細化効果はほとんど減少しないことが明らかで ある。

他元素を添加した場合は鋯込温度の影響は，Pおよび As を添加した場合と同様な傾向を示し 鋳込温度が低く なれば若干大きくなり， $800^{\circ} \mathrm{C}$ 以上ではあまり影響はな い。また再溶解の影響はなく，常に粗大な初晶が晶出す る。

\section{3 実験結果の考察}

本実験の結果から過共晶 Al-Si 合金の鋳造組織に現わ れる初晶 Siを微細化する添加元素は，P および As であ り，若干効果が現われる元素はBa, Sbであることがわか つた。

添加量については，約0.03\%添加すれば効果は顕著で ある。鋳込温度は $800^{\circ} \mathrm{C}$ 以上 $900^{\circ} \mathrm{C}$ 位がもつとも効果が あることが明らかになつた。

以下 $\mathrm{P}$ 打よびAs を添加することにより初晶 Siが微細 化される機構を考察する。この微細化機構を究明するた めには，他の源加元素に比較し，PおよびAsが溶湯に対 して特異な作用を持つか否かについて検討する必要が る。

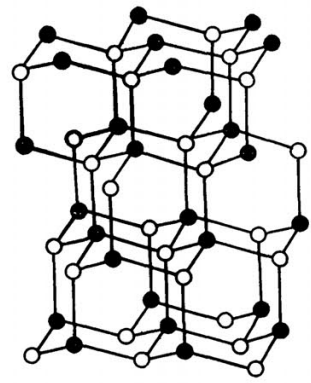

○ -..Al, •...P or As

Zn S Type

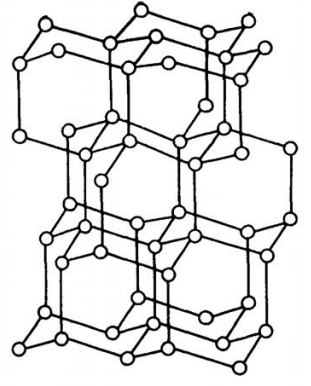

O--- Si

Diamond Type
Fig. 4 Schematic crystal structure of $\mathrm{ZnS}$ type and diamond type.

本実験において, 添加元素として 選択した元素は $\mathrm{P}$ と同族の元素として, P, As, Sb, Bi の 4 種類であり, 一 方Alと何らの刑で化合物を作りうるだろらと考えられる 元素としては $\mathrm{P}, \mathrm{As}, \mathrm{Ba}, \mathrm{Sb}, \mathrm{Ca}$ の 5 種類である。ただし $\mathrm{Na}$ はそれらに該当しないが共晶 $\mathrm{Si}$ 微細化する元素で あるという理由から添加元素として採用したものであ る。以上のごとく添加元素の物理的, 化学的性質として は同様な性質なものを選んだ訳である。しかし，これら の諸性質中でP 扝よびAsについてのみ特暴な性質が見出 されるならば，この微細化機楧を究明するための一因子 を把握できると考える。

これら元素のフッ点, 蒸気圧など物理的性質について も，現在の物理的データから P および Asについて特異 な数值はえられないのである。Al-Si- $(x)$ なる 3 元素の平 衡状態図を比較してみると，これら添加元素はいずれも AlおよびSiに対する溶解度は小さく，他元素に比べPお よびAsについて，初晶 $\mathrm{Si}$ が晶出する過程に特殊な反応 も存在しない。それ故本実験の考察に際し, 溶湯と添加 元素との化学反応を考えるため，柴田 ${ }^{3)}$, 桐山( ${ }^{4}$ および Hansen $5^{5)}$ の文献から諸データを引用し，その化合物 および結晶構造を比較した。Table 3 は各種添加元素と 化学物, 結晶㤽造および格子常数をまとめたものであ る。

Table 3 から解かる通り溶湯中に各種元素を添加した 場合，存在しらると考えられる化合物は， $\mathrm{Al}$ との化合物 として, $\mathrm{AlP}, \mathrm{AlAs}, \mathrm{AlSb}, \mathrm{BaAl}_{4}, \mathrm{CaAl}_{4}$ である。これら 化合物の結晶構造についてみると，AlP, AlAs および AlSb は ZnS 型で Fig. 4 に示すごとく，Si の結晶構造 であるダイヤモンド型とまったく同類である。一方それ らの格子常数を比較すると, AlP および AlAs はその数 值がSi の格子常数に非常に近似している。AlSb は結晶 構造は $\mathrm{Si}$ と同類であるが格子常数の差異が相当大きいの である。すなわち本実験において添加した元素中，P と 
As汢他元素に比し結晶構造㧍よびその格子常数が $\mathrm{Si}$ 之非 常に類似した化合物を生成するものであることが明らか となつた。しかし溶湯中に実際にAIPやAIAS が生成し うるか否かの疑問が残る。このことに関して, AIP は溶 融 AlにPを加えると, $800^{\circ} \mathrm{C}$ 以下の温度で生成され，一 度生成された AIPは $1000^{\circ} \mathrm{C}$ の融点を持ち分解することは ない(6)とされ，一方 AlAsは溶融AlとAsとから約 $800^{\circ} \mathrm{C} て ゙$

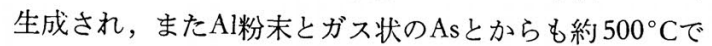
生成される化合物であり，その融点は $1200^{\circ} \mathrm{C}$ である ${ }^{5}$ と 述べられている。以上のことからAl-Si合金の溶湯中に $\mathrm{P}$ およびAsを添加すると, AlPおよびA1Asが溶湯中に生成 されうると推測する。

以下上述の推測を基に実験結果を考察する。本実駼の 冷却速度の影響を見ると，微細化に効果のあるPおよび As を添加した場合，他元素の添加に比べると冷却速度

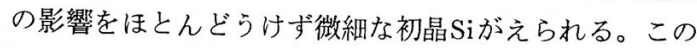
実験効果を Tammann らの凝固に関する核の生成とその 成長の理論より考察すれば，他元素の添加の場合，冷却 速度が大になれば晶出する結晶が微細になることは急冷 による成長速度の抑制によるものとして説明しうる。一 方 PおよびAs添加の場合は, 冷却速度の影響を受けない ことから, 成長速度よりむしろ核の生成に関する因子が 結晶の晶出に際し律速的役割を持つものと考える方が妥 当である。すなわち凝固に際し非常に多数の核が生成さ れるかまたは溶㷖中に核となりうる凝固金属とは異種の 微粒子が存在するかが問題となる。前述のごとく，Pお よびAsの添加により溶湯中に初晶 $\mathrm{Si}$ と結晶構造および格 子常数も非常に類似したAIPおよびA1Asなる化合物が存 在すると考えられる。

この微粒子が多数溶湯中に存在することにより, これ らが凝固に際し初晶 $\mathrm{Si}$ の晶出核として作用するものと考 えれば冷却速度の影響を受けず微細な初晶 $\mathrm{Si}$ が晶出する 実験結果を説明しうる。

$\mathrm{P} お よ ひ ゙$ As を添加した場合, 添加量と初晶 Si の関係 Fig. 3 を見ると, 添加量 $0.05 \%$ 以下になるとAs 添加の 方が初晶 Si が若干大きくなる傾向がある。しかし添加量 を重量パーセントで表わしたものであるので，これを原 子パーセントに換算すると, Pの原子量 30.98, As の原 子量 74. 91 であるので同者の関係はほぼ同様な曲線とな る。このことはP拈よびAsがAlと化学当量的に 1 対 1 の 化合物，すなわち AlPおよびAlAs を生成することにな り，これら化合物が初晶 $\mathrm{Si}$ の晶出核として作用すると考 えれば，添加元素の原子パーセントに比例し，核となり うる化合物もその割合で生成されることになり，P执よ び As の添加量を原子パーセントで表わせば同一の効果 を示す理由を説明しうる。

しかしこの考え方には，添加量と含有量が等しいと考
Table 4. Comparision of cooling curves for added elements.

\begin{tabular}{l|r|r|r|r}
\hline $\begin{array}{l}\text { Added } \\
\text { elements }\end{array}$ & $\begin{array}{l}\text { Freezing } \\
\text { temp. } \\
\left({ }^{\circ} \mathrm{C}\right)\end{array}$ & $\begin{array}{c}\text { Eutectic } \\
\text { temp. } \\
\left({ }^{\circ} \mathrm{C}\right)\end{array}$ & $\begin{array}{c}\text { Solidifica- } \\
\text { tion time } \\
(\mathrm{min})\end{array}$ & $\begin{array}{c}\text { Critical } \\
\text { angle at f.t } \\
(\theta)\end{array}$ \\
\hline none & 682.3 & 577.5 & 36.7 & 160 \\
$\mathrm{P}$ & 682.4 & 577.4 & 34.1 & 150 \\
$\mathrm{As}$ & 682.4 & 577.3 & 34.2 & 151 \\
$\mathrm{Na}$ & 681.1 & 571.8 & 37.5 & 160 \\
$\mathrm{Sb}$ & 682.0 & 577.5 & 37.8 & 161 \\
$\mathrm{Ca}$ & 681.5 & 574.4 & 38.1 & 165 \\
$\mathrm{Bi}$ & 697.7 & 576.0 & 40.2 & 173 \\
\hline
\end{tabular}

えているので疑問がある。実際には，これら元素は添加 に際し，多少は酸化損失するため, 添加量を完全に溶湯 中に含有せしめることは, 理論的にも実験上も困難であ る。この問題についてさらに明確な議論を進めるために は, 源加量と含有量の関係を明らかにする必要がある。 $\mathrm{Al}-\mathrm{Si}$ 合金中の $\mathrm{P}$ の添加量と含有量については多数の分 析結果が他の研究者によりなされている。

Mill ${ }^{72}, \mathrm{Kuhn}^{8}$, Ashton, ${ }^{9)}$ らは Al-Si 合金中の P を, 塩酸で溶解しうる “solvable P” と塩酸で溶解できない “insolvable P”すなわち Si 中に含有されるP “insolvable P”について分析を行なつている。その結果によれば, Pをいかなる形で添加するかにより多少の相違はある が，添加量と insolvable Pとの関係は，添加量 $0.06 \%$ ま では添加量とともに含有量はほぼ比例して増加する。し かし添加量0.06\%以上になると insolvable P は添加量が 多くなつても変らないと述べている。以上のごとく, 添 加量 $0.06 \%$ まではSi中の含有量は添加量に比例し, それ 以上の添加量については変化はなくほぼ一定であるとい える。この実験結果が正しいとすれば，前述のPおよび As が化学当量的化合物を生成するとし，これらが同一 の微細化効果を有する理由として述べた推論はかなり妥 当性があると思われる。

再溶解により微細化効果が減少しない理由は，これら 化合物が比較的高温まで安定であり, $850^{\circ} \mathrm{C}$ 程度の温度 では分解し消耗することがないことを示すものである。 溶解を数度繰り返えすとわずかに微紏化効果が減少する のは，溶解を繰り返えす間にこれら化合物が凝集し晶出 核が減少するか，または化合物の微粒子自体がある程度 不純物を化学吸着することによると考える。

以上のごとく, 本実験結果より微細化機構を説明する にAlPおよびAlAsが溶湯中に生成され，これが初晶 $\mathrm{Si} の$ 晶出核として作用すると考えれば，実験結果を矛盾なく 説明しうるのである。

\section{3. 冷却曲線による凝固過程の検討}

\section{1 実験方法}

本実験では過共晶Al-Si合金（前実験と同一試料）に添 


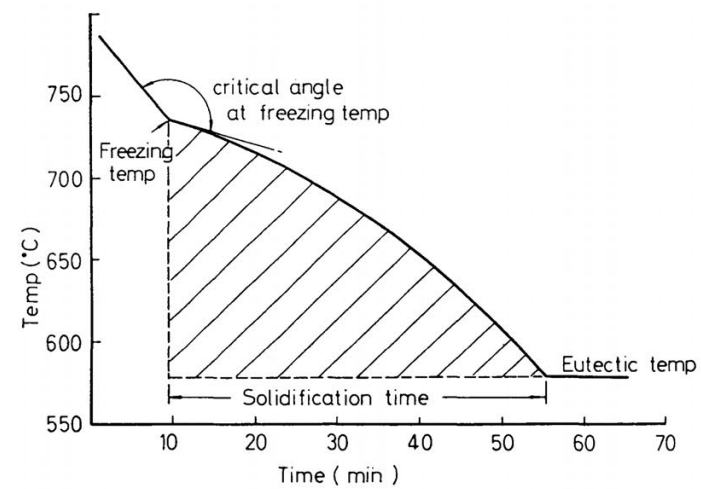

Fig. 5. Schematic graph of cooling curve by way of explanation.

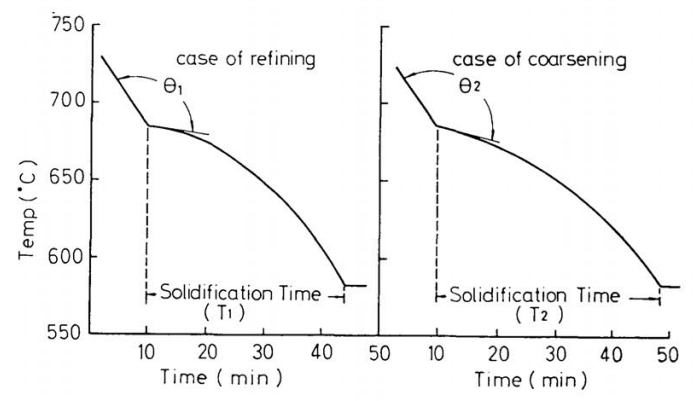

Fig. 7. Comparision of cooling curves for the case of refining and coarsening.

加元素を添加した場合，その凝固過程を検討するため， 温度範囲を鋳込温度から共晶温度までとし，その間の冷 却曲線を温度一時閒について求めた。試料は正確に 100 gr 天科にて科量し, アルミナルツボ中にて溶解し, 溶解 温度 $850^{\circ} \mathrm{C}$ で扔のおの添加元素を $0.03 \%$ 添加し炉中冷却 を行なつた。炉の冷却速度を一定に保つため，電流打よ び外的条件を調整し，冷却速度が一定になる条件を求め 冷却速度を $5^{\circ} \mathrm{C} / \mathrm{min}$ に保つた。

温度測定にはPt-PtRh 熱電対を電位差計に接続し微小 な電位.差をも極めて精密に測定し, 時閒一温度曲線を求 めた。同様な条件の下で電磁オシログラフにより泠却曲 線を求めて両者を比較し冷却曲線を検討した。

\section{2 実験 結果}

各種の添加元素を添加した場合, 冷却曲線から凝固温 度 (初晶 $\mathrm{S}$ の晶出開始温度), 共晶温度, 凝固時間(凝固温 度から共晶温度までに要する時間), 凝固温度における折 点の角度を比較のため表に括めたものが Table4である。

Fig. 5 は冷却曲線の説明のために典型的なグラフを示 したものである。

凝固温度についてみると，添加元素によりわずかの差 異は存在するが，お扔むね $682^{\circ} \mathrm{C}$ となり大した変化はな い。ただしBi を添加した場合には逆に凝固点が約 $15^{\circ} \mathrm{C}$

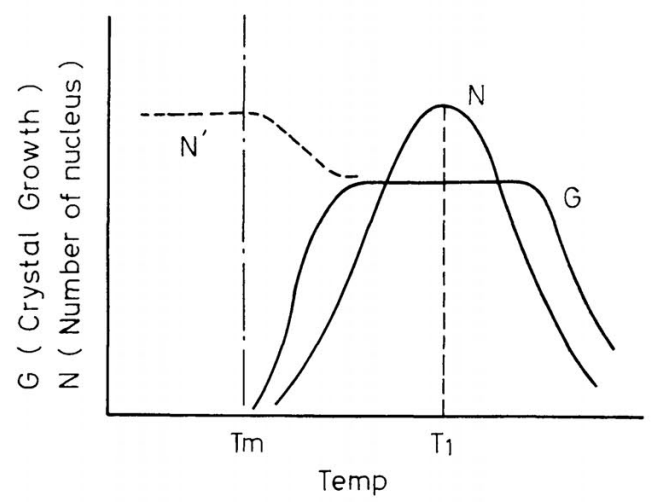

Fig. 6. Explanation of relation of crystal growth and number of nucleus.

高くなるのは注目に值する。

共晶温度は $\mathrm{Na}, \mathrm{Ca}$ を添加すると他に比べ約 $4 \sim 6^{\circ} \mathrm{C}$ 低 下する。その他はお打むね $577.4^{\circ} \mathrm{C}$ で他元素を添加しな い場合とほとんど差異は認められない。

凝固温度加ら共晶温度に達する凝固時間は，P，As を 添加寸ると, 他元素に比べ $3 \sim 4$ 分短くなり, 時間的に 早く共晶温度に達する。添加元素のない場合に比べると $\mathrm{P}$, As を除く元素はいずれもこの凝固時間が長くなる傾 向が現われ，Bi を添加した場合は特に長くなる。

冷却曲線の形状を見る手段として，凝固温度における 折点の角度を比較してみると, P, As と他元素を添加し た場合, その角度に約10度の差異が認められ, 冷却曲線 上に折点が明瞭に現われる。

以上の実験結果から, 初晶 $\mathrm{Si}$ を微細化する添加元素で あるPおよびAsを添加すると他元素の添加に比較し冷却 曲線の形状において, 凝固温度における折点の角度が約 10 度少なくなり折点が明瞭に現われ，凝固時間（凝固温 度から共晶温度に達するまでに要する時間）が短かくな ることがわかつた。な扮凝固時間に放出されるエネルギ 一は溶融状態と固体状態のエネルギー差を示すものであ るから㠜固間に放出されるエネルギーを比較すれば凝固 晶出する初晶 $\mathrm{Si}$ の量を比較できると考えられる。本実験 で求めた冷却曲線について, Fig. 5 の斜線に囲まれた部 分の面積を凝固に際し放出されたエネルギーの尺度と考 え,これらの值を比較した。その值はBiの場合を除いて ほぼ一定であることがわかつた。このことがら，この間 に晶出した $\mathrm{Si}$ 量は, 初晶 $\mathrm{Si}$ が微紐化または粗大化され ることのいかにかかわらずおおむね一定であると考えら れる。

Biを添加した場合の泠却曲線については, 他の粗大化 効果を有する元素の場合とも異なつた形状を示し凝固温

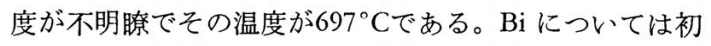
晶Siが針状または毛羽状を示すなど特異な形状を示すこ となどから，このことを明らかにするにはAl-Si-Bi 3元 
素平衡状態図を明らかにする必要があると思われる。

\section{3 実験結果の考察}

以上の実験結果を基に，各種添加元素を添加した場合 の凝固過程を冷却曲線の相違から考察する。金属の凝固 に関しては，核の生成とその核の成長に関する理論が定 性的には金属の凝固過程をよく説明をよく説明すること ができる。凝固が進行するには，核の生成と核の成長が 必須の要因であり，これら2つの要因の関係はFig. 6 に 示す通りである。すなわち核生成数はその速度はある一 定温度 $\left(\mathrm{T}_{1}\right)$ を中心にした純然たる確率分布的様態をもつ て起る現象であり，一方核の成長速度はある温度領域に わたつた広い曲線で示されるものである。したがつて 凝固晶出する結晶の大ささはこの 2 つの要因に左右され るものである。Al-Si 合金 (過共晶) の溶融状態から初 晶 Si が凝固晶出する場合は Alと Si の溶融混合相から Si のみが単独に晶出する過程を見れば純金属の凝固の理論 である前述の思考過程を適用し得ると考えることができ る。

Fig. 7 は微細化効果の著しいP および $\Lambda$ s を添加した 冷却曲線と粗大化傾向を有する元素を添加した冷却曲線 を説明の都合上典型的に図示したものである。

粗大化傾向または微細化效果のない元素を添加した試 料の泠却曲線は凝固温度における折点の角度 $\left(\theta_{2}\right)$ は $\theta_{1} よ$ り大で冷却曲線は緩かな勾配で変化する。これらの場合 は凝固温度に達しても初晶 Si が凝固晶出するために必 要な晶出核が十分存在しないので, 凝固の初期では結晶 の成長は核数に比して大であるため結晶は大きく成長す

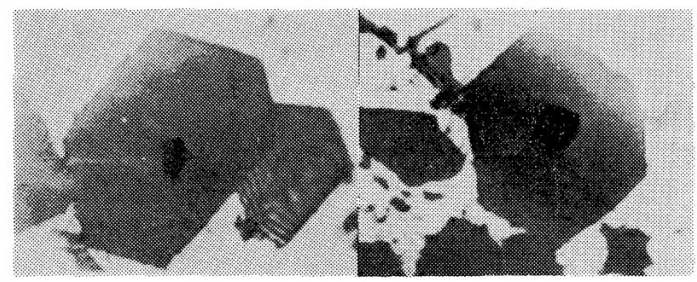

a) added $0.05 \% \mathrm{P}$

b) added $0.05 \%$ As.

Photo. 3 Microstructure of refining Si $(\times 2000)$
る。

また凝固晶出する時間が長くなるのは，溶湯中に生成 される比較的少数の核に対 LSi 原子が払散凝集し結晶面 に吸着され初晶Siを晶出するから時間も長くなるのであ る。微細化効果の著しいPおよびAsを添加した試料の冷 却曲線は，凝固温度における折点の角度 $\left(\theta_{1}\right)$ が小さくな り，折点が明瞭に現われる。これはこの温度で凝固晶出 が急激に起り初晶Siが晶出することを示している。この ことは凝固温度においてすでにSiが晶出するに適した条 件が存在することを示している。この条件として著者ら は溶湯中に初晶 $\mathrm{Si}$ を晶出するに適当な晶出核が存在する と考えた。すなわち Fig. 6 に点線で表わした $N$ なる核 が存在するとしこれが初晶 $\mathrm{Si}$ の晶出核として作用するも

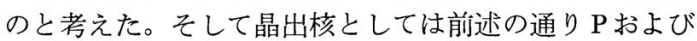
Asを溶湯中に添加すればAlPおよびAlAsが生成されると 考えられるので，これら化合物が初晶 $\mathrm{Si}$ の晶出核になり 得ると考える。

以上のごとく冷却曲線に現われた差異は溶湯中に既存 する思種の核としてA1PおよびA1Asが存在することを示 していると考えた。

\section{4. 電子顕微鏡による初晶 Si の観察}

\section{1 実 験 方 法}

前述のように，PおよびAsを溶湯中に添加すれば，こ れらがAlと化合しAIPおよびAlAs化合物を生成し微粒子 として溶湯中に多数存在するため，これらが初晶 $\mathrm{Si}$ の晶 出核として作用するものと考えれば実験結果を矛盾なく 説明できることがわかつた。

本実験ではこれら微粒子または化合物の存在を確認す る目的で電子顕微鏡を用いレプリカ像の観察により㛟討 を試みた。

試料は前実験において0.05\%添加した試料を用いた。 この試料をバフにて研磨し, 研磨面のレプリカを腐触し た場合および腐食しなこの状態について観察した。

研磨面の腐食に用いた溶液は a) 苛性ソーダ 10\% 溶 液，b）フツ化水素 $0.5 \%$ +塩酸 $10 \%$ 溶液の 2 種類であ

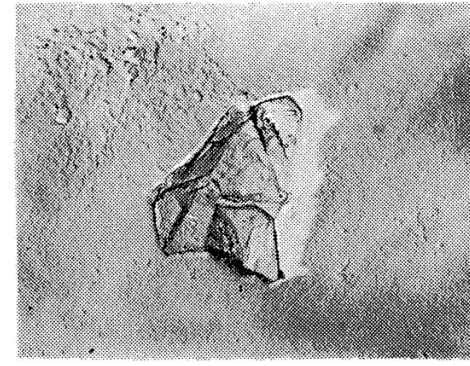

a) A tiny crystal in primary $\mathrm{Si}$ $\times 10,000$

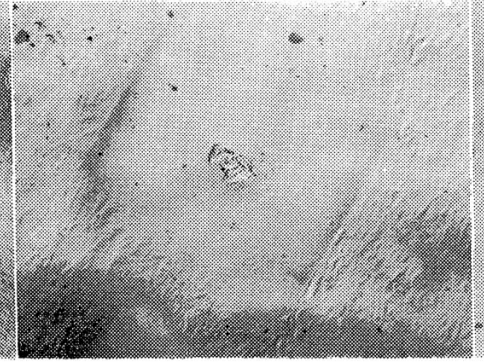

b) Primary Si and a tiny crystal $\times 2,000$

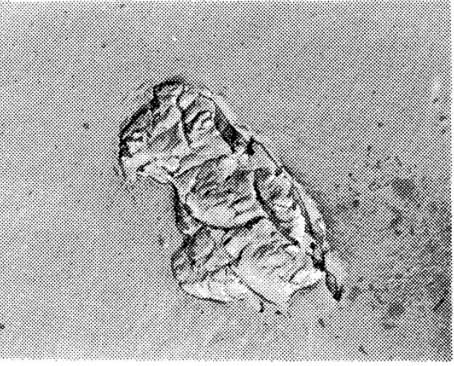

c) A tiny crystal of left (b) $\times 10,000$

Photo. 4 Electron micrograph of primary Si and a tiny crystal (non etch). 


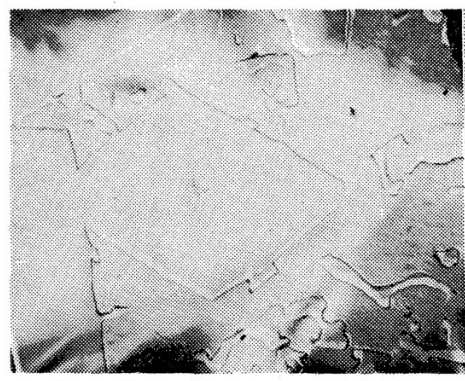

a) $\mathrm{NaOH} 10 \%$ etched $\times 2,000$

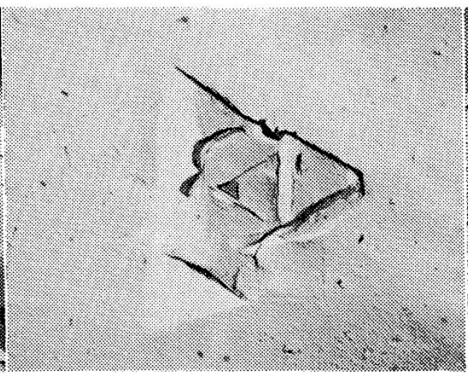

b) $\mathrm{NaOH} 10 \%$ etched $\times 10,000$

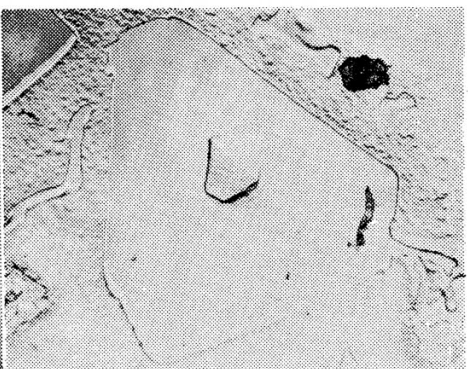

c) $\mathrm{HF} 0.5 \%+\mathrm{HCl} 10 \%$ etched $\times 2,000$

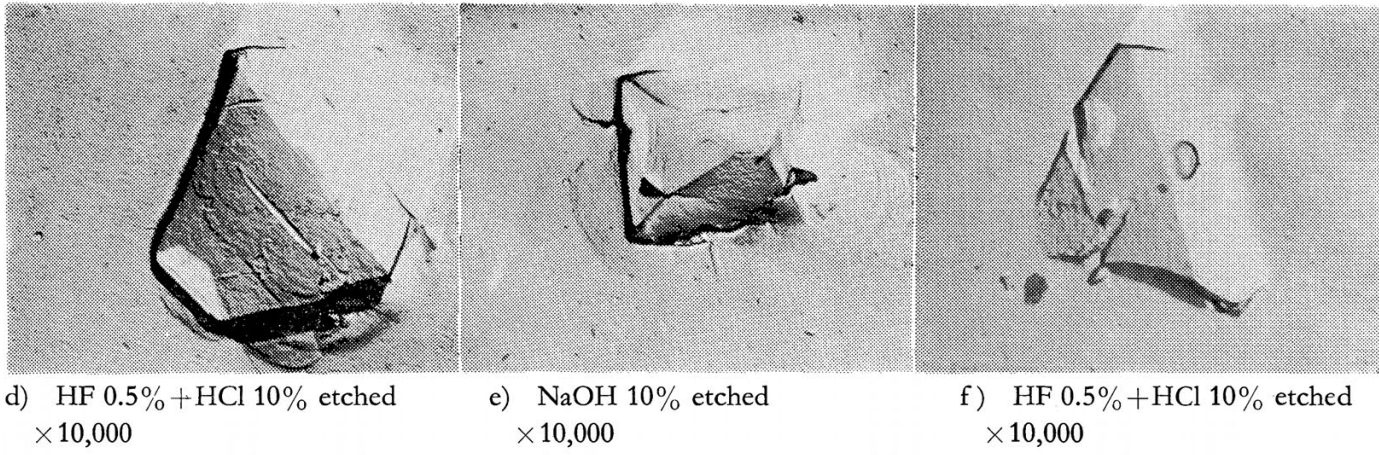

Photo. 5 Electron micrograph of primary Si and a tiny crystal (etched).

\section{る。腐時間は $10 \sim 20$ 秒とした。}

\section{2 実験 結果}

光学顕微鏡により微細化された初晶 $\mathrm{Si}$ を観察すると, 初晶 $\mathrm{Si}$ のほぼ中央附近に黑く見える異物が存在する。こ の初晶 $\mathrm{Si}$ を高倍率で観察したものが Photo. 3 である。 これらの試料を腐せず電子顕微鏡で観 察した写真が Photo. 4 であり, Photo. 4 の a) は初晶 Si中に存在する 微小な結晶性異物である。Photo. 4, b) 抢よび c) 初晶 $\mathrm{Si}$ 中の微小異物の状態とその巽物を示している。

Photo. 5 は同栐に試料の研磨面を前記の腐食液でそれ ぞれ腐した初晶 $\mathrm{Si}$ および異物の腐食痕跡の電子顕微鏡䆘 真である。以上のごとく初晶 $\mathrm{Si}$ 中の異物は, 結晶性を示 し初晶 $\mathrm{Si}$ の結品面と相互に関連が存在することがわかつ た。

Photo. 5 のa) 抢よびb) または c) およびd) はそれ艺 れ同一個所の写真であるが明膫に初晶 $\mathrm{Si}$ の中央附近に異 物が存在し, しかも, その結晶の形状が初晶 $\mathrm{Si}$ と相似関 係を有していることを示している。

\section{3 考察}

以上の電子顕微鏡による観察から，PおよびAsを添加 した試料の初晶Siには中央附近に異物が認められ, しか も結晶性を示し，その腐食痕跡は初晶 $\mathrm{Si}$ の形状と相似関 係を明瞭に示しているものも存在する。

初晶 $\mathrm{Si}$ の晶出過程を考えると, まず晶出核となる微小 なるSi自身の核または異物の晶出核が存在することが必
要である。そして異物が晶出核として作用するためには その異物が $\mathrm{Si}$ と結晶構造扝よび格子常数が非常に類似し ている必要がある。電子顕微鏡で観察した異物はその腐 食痕跡から見ると, 初晶 $\mathrm{Si}$ の結晶面と相互に関連を有し ており微小異物を中心に結晶が成長したことを示してい る。しかも苛性ソーダ10\%溶液で腐されることから，い わゆる “etch pit”でないことは明らかである。それ故， この異物をAlP拉よびAlAsと考えると，これらがSi と結 晶構造およびその格子常数が非常に類似していることか ら, この異物が結晶性であり, 初昆 $\mathrm{Si}$ と相似関係が認め られるもの考えた。異物の大きさを顕微鏡の倍率から換 算すると $2 \sim 3 \mu$ となることが解つた。次の仮定を設け て初晶 Si 中の AIP および P の量を計算により求めてみ る。

(1)初晶Si はすべてAlPを含有する。(2).AIP の大きさは 3侯あるる。(3)AlPは立方体をなしている。(4)初晶 $\mathrm{Si}$ の大 きさは平均 $0.02 \mathrm{~mm}$ とする。

以上の仮定のもとで初嵌Si 中のAIP 計算すると 0.34 \%となり，合金全体では Pは 0.014 \%含有していること になる。Al-Si合金中に含有しているPの中“insolvable P” を初晶 Si 中の $\mathrm{P}$ 量と考えると Ashton らの分析結果では

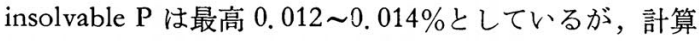
の結果はこの值によく一致する。もちろんこの計算の基 となる仮定を設けているので，速断はできないが，計算 值と分析值がよく一致することは逆に仮定にあまり誤り 
がなかつたとも考えられる。以上の考察から考えて電子 顕微鏡による観察により認められる異物は AIP および AlAs と判断した。なお確実な結果をうるにはマイクロ アナライザーによる分析を行なら必要があると考える。

\section{5. 総括}

以上の実験結果から過共晶 $\mathrm{Al}-\mathrm{Si}$ 合金の錹造組織に現 われる初晶Siを微細化するにはP㧍よびAsを溶湯に添加 すれば顕著な効果があることが明らかとなつた。

この微細化の機構として,PおよびAsを添加すると溶 湯中でAlと化合しAlPおよびAlAsを生成し，これが初晶 $\mathrm{Si}$ の晶出に際し晶出核として作用するものと考えると, 本実験の結果を矛盾なく説明しうることが解つた。

以下微細化機構についてさらに検討を加える。

一般に結晶を微細化するには本質的に次の 2 つの要因 を满足することが必要である。

第 1 に, 溶融合金中に均一に分布された多数の晶出核 が存在するか，凝固に際し直ちに多数の核が生成される こと。

第 2 に, 凝固中結晶の成長を抑制すること。

第 1 の要因については, 結晶の成長が進行しうる温度 は, 核生成温度より高い, すなわち固体一液体界面はどの 点でも溶融金属が核生成温度に冷却される前にすでに結 晶の成長温度に達しているので紹晶は粗大に成長する。 それ故何らかの方法で, 晶出核を多数生成または存在す る処理をすればよい。本実験では P およびAs を添加し AlPおよびAlAsを溶湯中に生成せしめこれが晶出核とし て作用するものと考えた。他元素を添加した場合, 化合 物の生成は考えられるが晶出核としての条件に欠けるの である。

第 2 の要因については, 溶融合金から初晶が晶出する 過程は晶出する原子が晶出核へ向つて应散し, 規則的に 配列する過程であるので，溶融合金中で晶出する原子の 拡散速度を遅延させるか，に泠却速度を速くすることに より結晶成長の機会を少なくすることが考えられる。

$\mathrm{Al}-\mathrm{Si}$ 合金中の Si 原子の扡散速度は, 添加元素の種煩 により若干相違が認められ，津村らは，Na を添加する と, Si 原子の拡散速度を遅くすると述べている。しか し, 凝固中に拉ける結晶成長速度は搪散速度の若干の相 違は結晶の微細化または粗大化を律速するものでなく， むしろ，急冷による抑制作用の方が律速するものと考え る。

P および As の添加では泠却速度の影響をほとんど受
けず，他元素の添加の場合には大きな影響を受けている ことから, 他元素の微細化を律速するものは冷却速度に よる急冷の效果である。P およびAsを添加した場合は, 第 1 の要因が結晶微細化を律速するものと考える。

PおよびAs を添加した場合, 初晶 $\mathrm{Si}$ の晶出核として 作用するためには，次の条件を満足していなければなら

い。(1)溶湯中において AIP および AlAs を生成するこ と。(2)初晶Siの核となるために, Si の結晶面と晶出核の 結晶面に歪がないこと，才なわち結晶構造および格子常 数が類似していること。(3)AIP 执よび AlAs が Si 原子と 化学結合をなしうること。これらの中に(1)と(2)について はすでに述べたが(3)の化学結合の問題額については, mitscherlich は, 無機化合物について, 類似の結晶幾何 学的関倸, 類似の対称関係などを有するものは, 混晶や 層晶を形成する能力があり，あるい互にはならんで析 出することができることを見出している。以上のことか ら，PおよびAsを添加すれば晶出核として作用しらる条 件を満足しているといえる。

電子顕微鏡観察により認められる異物の腐食痕跡は, 初晶 $\mathrm{Si}$ とその結晶形に類似性がある。このことは $\mathrm{Si}$ と異 物が結晶構造が類似しており, この異物に対しSiが拡散 し結晶の成長が起つたことを示している。

またSiを溶解しない苛性ソーダ溶液で腐食されること からSiの腐食痕跡でないことが確かである。

以上のごとく, 実駼結果扔よびその考察から初晶 $\mathrm{Si}$ 微細化機構は, 溶湯中に生成されるAlPおよびAlAsが初 晶Siの晶出核として作用することによるものと考えられ る。

\section{参 考 文 献}

1) K. Lobberg, E. Schulz: Z. Metallkde, 43 (1952) 50.

2) A. Cibula: J. Inst. Metals, 76 (1949-50) 321.

3) 柴田: 結晶無機化学

4) 桐山: 構造無機化学 ( I II II )

5) M. Hansen: Consititution of Binery alloys (1958).

6) E. Mitscherlich: Ann. Chcm. Pbys., 19 (1921) 141.

7) E. C. Mills: Mctal Industry, 20 (1962) 492.

8) M. Kuhn: Fonderil, 149 (1958) 279.

9) S. T. Ashton: Metal Irdustry, 19 (1961) 123 